\title{
Correlates of Talent Management: An Empirical Analysis
}

\author{
${ }^{1}$ Ravindra Sharma, ${ }^{2}$ Geeta Rana, ${ }^{3}$ Shivani Agarwal \\ ${ }^{1}$ Assistant Professor ,Swami Rama Himalayan University, Jolly Grant, India \\ ${ }^{2}$ Associate Professor, Swami Rama Himalayan University, Jolly Grant, India \\ ${ }^{3}$ Assistant Professor, KIET School of Management, KIET Group of Institutions, \\ Delhi-NCR, Ghaziabad, India \\ ${ }^{1}$ ravindrasharma97@gmail com
}

\begin{abstract}
This paper attempts to measure talent management in India industry, using a standard questionnaire (Jayaraman et al. 2018). The data was obtained from a randomly drawn group of 378 managers from India's IT, telecommunication, power and Banking industries. The current study reports important co-relations among managers and talent management of age and hierarchy. ANOVA reported a significant difference in talent management between businesses and companies (technology and ownership) although the organisational life cycle position wasn't significant. This study concludes with implications for practioners and explores areas for further research.
\end{abstract}

Index Terms-Talent Management, Organizational Attractiveness, Prestige, Career Development, Economic Rewards, Indian Industry.

\section{INTRODUCTION}

THE LACK of clarity at the talent level necessary to sustain performance is not precisely what companies need to succeed in today's competitive and challenging market climate. However the best differentiator between performance and loss would be a meticulous, cyclical and continuing procedure of talent management. Organizations are blank shelf lacking abilities. When there is a company of consistent talent management strategies, it goes to the precipice. Lawler (2008) points out there are no way to achieve the pace of transition, the degree of creativity and consumer attention expected without concentrating on human resources across a growing array of companies." He adds that business strategy should be focused on talent factors which should contribute to human resource management strategies in turn. This suggests that companies finding excellence in creativity, quality consumer care, fundamental systemic reform and other sectors involving large numbers of people ought to re-think their skills management strategy. Different reports describe important corporate performance drivers. Nategh (2005), for example: argues that the success of organisations involves creativity, speed, stability and incorporation. As companies encounter reductions in standards of output and lowquality goods and services, they reverse these deficits by handling talent (Alsakarneh \& Hong, 2015). Undoubtedly, organisations must have best practices in talent management if they want to succeed in this hyper dynamic and ever more nuanced global economy. An company is known to be an effective instrument for its achievement and sustainability, to recruit, participate, improve and maintain its workers with the correct skills and capabilities at all stages (Rana \& Sharma, 2019). The consistency and high quality of the employees of another company is challenging, if not difficult for an organisation to precisely duplicate. However a company is virtually willing and cheaply imitated to introduce a new offering. An company may still chase a competitive demand or lower the costs of its goods. In the modern age of globalization, creativity and analytical strength thus becoming the primary currency (Shahai \& Srivastava, 2012). In this dynamic market climate, most companies, in specific workers, understand that they have a strategic edge in terms of intangible assets (Chabault et al. 2012). Both of these arguments stress the important role played by talent management in corporate performance and sustainability and why modern companies should pay critical attention to the strategies of talent management. It is such a shame that most companies in the 21 st century are now creative poachers rather than talent creators. They would recruit skilled people and achieve comparative edge (Sharma et al. 2018). They would enjoy something. This is in accordance with Michaels et al. 2001 proposal that the 'fight for talent' will continue for the next two decades owing to the lasting economic and social influences. In order for companies to survive this battle and remain before the extreme global rivalry, it is therefore necessary to use better practises for talent growth in this modern business age.

It is in this context, that talent management practices assumes importance (Paul, 2013) this requires acquisition, recruiting, growth, retention and support when fulfilling the needs of the company simultaneously. The current study aims at the measurement of talent management, through an indigenous scale, and further attempts to link contextual factors to the talent management. The paper moves on to the theoretical framework of the construct, to a working definition of talent management, the research questions, the theoretical model to be tested, methodology, instrumentation used, and finally results and discussions. 


\section{LITERATURE REVIEW AND HYPOTHESIS DEVELOPMENT}

Talent management is a process that is essential for businesses to ensure that their existing and future market goals are satisfied with the quantity and quality of people (Wellins, Smith, \& Erker, 2010) Talent management is a holistic human capital maximisation approach that helps an organisation to build community, engagement, expertise and ability by streamlined talent acquisition, development and implementation processes in accordance with the company's goals for short-and long-term performance. Essentially, the purpose of talent acquisition would be to ensure that the required talent is needed at the appropriate time and place to meet the company's strategic objectives. Implementation of adaptive approaches or processes aimed at optimising the training and development of people and retaining the required skills and readiness to respond to current and future business demands (Sparrow et al.2015; Sharma et al 2019; Rana \& Goel 2017). Talent management thus works in a proactive, inclusive and profound way. This can be told by the sense in which the corporate leaders of a company take into consideration the value of talent for the productivity of their business (Krishnan et al 2017; Rana et al. 2012 ).The HR divisions of small medium-sized companies, with individual employees in several countries are generally smaller and often more operational than political. Hunt, 2014 emphasised that TM is not only a traditional HRM, but that it incorporates modern knowledge and ideas in order to fulfil the goals and objectives of the organisation. HRM's emphasis on the development of general staff and its concentration on equality have become the primary difference between HRM and TM, whereas TM focuses on a particular group of employees identified as high-potential performers. Latukha,2018 concluded that the slowdown of the global economy and the subsequent labour loss market will clearly reduce the pressure on companies to manage talent. They also echoed the presence of a limited future pool of extremely trained administrators. It is possible to claim that big MNCs are increasingly deploying TMS to help locate their talent (Rana et al. 2016). Compared to Human Resource Information Systems (HRIS) and may in turn, become part of the ERP, TMS is often applied and used. Various publications have demonstrated the increasing importance of these TMS in talent management (Stahl, 2012; Rana et al. 2012)).

The talent management strategies of an organisation, where staff are involved, motivated and satisfied, therefore help to minimise turnover rates. It also benefits the organisation in that Talent Management allows the company, where certain positions are vacant, to prepare for the most possible candidate. In-house development is also a systematic solution to talent management in terms of succession planning. It is also important for companies to attain its goals in a competitive world in order to motivate and encourage their employees to carry out their duties and responsibilities properly. The present study reflects on this disparity in analysis and attempts to relate talent management practices to the company size, organisational type and life-cycle of the enterprise. Data were obtained from line managers and HR managers, as were background changes in age, race and educational skills. Hierarchical levels of top, middle and lower levels and their linkages to talent management practices were also established.

\section{RESEARCH QUESTIONS}

This study address the following research questions

1. What are the relationship between the variables of TMP (Jayaraman et al. 2018) and the contextual variables of firm size, firm organizational life cycle stage and firm type?

2. What are the relationship between background variables of managers and TMP? Whether gender, age and educational qualifications differ in the perception of TMP.

\section{RESEARCH DESIGN}

The author used a survey approach to respond to the study concerns. The technique was defined by Kerlinger (1973). Two sampling procedures were necessary. In the first point, Indian organisations have been selected by random choice from India's national capital region from the A+ business school database accessible in New Delhi. To complete the questionnaire, either HR or line, 567 top, medium and senior managers of these 20 organisations was contacted at random. The sampling method of 567 managers comprised 378 questionnaires. The 87 questionnaires were either incomplete or refused by the managers.

\section{INSTRUMENTATION}

A large amount of studies have concentrated on talent management practices and various researchers have various dim for connecting talent management practices (Chen, 2012; Hung, 2013; Yu et al. 2004). The tools embraced by such researchers have several parallels with respect to subjects, and the original version of the TMP may be said to have been applied to a large extent with little variation in factor structure. Jayaraman et al. 2018 modified this scale in Indian culture, and some items were removed, and 26 items were included in the final instrument in Indian culture. The scale identifying four dimensions such as Identifying critical positions (4 -items), Competence training (6 items), Development (5 items), Reward management (11 items). The reliability coefficients for these dimensions are $.81, .87, .86$, and .85 , respectively. Participants were asked to respond on a 5-point Likertscale.

\section{DATA ANALYSIS}

To answer the first two research questions Person's correlation and ANOVA were calculated while to answer 
the third objective, stepwise regression analysis was selected. Inter-item and Cronbach alpha were also calculated.

\section{RESULTS AND DISCUSSION}

When we examine table 1 , which depicts the correlation analysis, we find the hierarchical level of the managers and age of the managers to be significantly correlated to the TMP (.17 and .26 respectively). Interestingly age and TMP have a perfectly negative relationship, i.e. if age goes up, TMP will come down (Thunnissen, \& Buttiens, 2017). The rest of the variables were not significant at $\mathrm{p}=.001$ level. There was a non significant difference of gender, educational qualification and of HR manager may be attributed to this. This result does not fufilled the need for Ulrich's partnership role to move on to the line function and Ends like the skill and potential of an organization (Rana \& Rastogi, 2015). HR practitioners are focusing on ensuring that the strongest people get the correct certification in the right position at the right time. Talent rivalry rages and is projected to persist in an increasingly global knowledge economy (Rana \& Sharama, 2019). HR professionals also collaborate with line managers to identify and build capacities such as company speed, innovation, collaboration, connectivity, quick change and cultural management. On the other hand TMP was found to be the highest in IT sector $(M=142.8)$, while lowest in the automobile sector $(M=100.5)$. When we refer to table 2, we find that the ANOVA between TMP and nature of industry is significant $(\mathrm{F}=1.234567$, df $=107$, $271, \mathrm{~F}$ probability $=.000)$ whereas table 3 depicts a significant ANOVA of type of ownership ( $\mathrm{F}=1.6783456, \mathrm{df}=$ $123,255)$ as also between the three groups of public, private and Multinationals organizations is significantly different, as also between the eight industrial sectors formed from the 12 organizations. The results of this analysis are supported by the Rout \& Satpathy (2020) report, in which the ANOVA of various Indian companies showed a large difference.

TABle 1: PeARSON's Co-RELATION BETWEen BACKGROUND VARIABLES AND TMP

\begin{tabular}{|c|c|c|c|c|c|c|c|}
\hline & $\begin{array}{l}\text { Hierarchical } \\
\text { Level }\end{array}$ & $\begin{array}{l}\text { Managerial } \\
\text { Type }\end{array}$ & Gender & Age & $\begin{array}{l}\text { Educational } \\
\text { Qualification }\end{array}$ & $\begin{array}{l}\text { Technical } \\
\text { Sector }\end{array}$ & TMP \\
\hline Hierarchical Level & 1 & & & & & & \\
\hline Managerial Type & .02 & 1 & & & & & \\
\hline Gender & $.11 * *$ & .05 & 1 & & & & \\
\hline Age & $.47 * *$ & .02 & $.17 * *$ & 1 & & & \\
\hline $\begin{array}{l}\text { Educational } \\
\text { Qualification }\end{array}$ & $.18^{* *}$ & .01 & $.13 * *$ & .03 & 1 & & \\
\hline Technical Sector & $.28 * *$ & .03 & .04 & $.26^{* *}$ & .07 & 1 & \\
\hline TMP & $.17 * *$ & .09 & .09 & $.21 * *$ & .003 & $.26^{* *}$ & 1 \\
\hline
\end{tabular}

Correlation is significant at the .01 Level (2-tailed)

TABle 2 SUMmary OF ONE WAY ANOVA OF VARIABLE OF TMP AND NATURE OF INDUSTRY

\begin{tabular}{|l|l|l|l|l|l|}
\hline Source & Sum of Squares & df & Mean Sqaure & F & Sig \\
\hline Between Gropus & 823.38672 & 107 & 7.975622 & 1.234567 & .000 \\
\hline Within Gropus & 9861.23416 & 271 & 5.673212 & & \\
\hline Total & 2341.64523 & 378 & & & \\
\hline
\end{tabular}

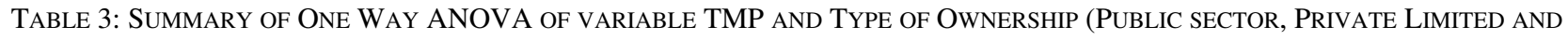
MULTinATIONAL FIRMS)

\begin{tabular}{|l|l|l|l|l|l|}
\hline Source & Sum of Squares & df & Mean Square & F & Sig \\
\hline Between Gropus & 66723.15678 & 107 & 7.975622 & 1.6783456 & .000 \\
\hline Within Gropus & 342987.13256 & 208 & 5.673212 & & \\
\hline Total & 234151.76231 & 378 & & & \\
\hline
\end{tabular}


ANOVA was significant for TMP and organization size. $(\mathrm{F}=1.28, \mathrm{df}=170,208, \mathrm{~F}=$ probability $=.012)$. This result is well supported by the study of Latukha, and Anna, 2019). If an organisation has to survive indefinitely, it has to invest money on development. Not just tangible objects, but also individuals. Each business is the mover to lift the valuation of the firm. Employees must constantly improve their talents, knowledge and experience to fulfil this idea. Only those jobs may represent flexible human resources, while new methods and technological developments often require more with any job position (Rana et al. 2019). That is why creative approaches to developing talent-based human resources are required in management processes. Many profitable companies have used talented carrier training systems to guarantee that the company develops. Sufficient money, desire and time are required for the development of structural talent. With the guidance of the management talented people need and want to take charge of their own development (Järvi et al. ,2020).

Further, when examine the TMP and organizational life cycle stage, we find the ANOVA resultto be insignificant $(\mathrm{F}=1.29864, \mathrm{df}=106,272$, Probability $=.012)$. This supports the findings of (Latukha and Veselova 2018). The acquisition of talent is a way of improving the productivity of human resources of each enterprise, regardless of its size. More research papers (B`rezinová and Vaiman et al. 2012; Collings et al. 2019; Rana, 2010). Study has studied the scale of business as an important element in the control of human resources. However, none of the analyses explored the relationship of talent acquisition and organisational size to our best understanding, as much of the results of the analysis apply to large multinational companies (Morley et al. 2015; Festing et al. 2013).

\section{CONCLUSION AND IMPLICATIONS}

To conclude, the current study lends credence to measuring TMP in Indian organizations, examine the management and business attributes that improve TMP, the nature of ownership and type of the industry, the organisational life and organisational life cycle stages, as well as the demographic variables of age, sex, HR or line managers. This is the rare Indian study that has empirically tried to relate the above variables to TMP, although there are philosophical connections. The research disadvantages exist since only the sectional specifics were concentrated in the survey. Future study will examine demographic data and establish TMP case studies. Future experiments may research several samples across cultures. In the case of talent management interventions, practical outcomes must be generated and constantly evaluated and questioned as to whether talent development takes place at the individual, team or organisational level. For a company to be able to continue for a longer period of time, it needs to expend its resources on expansion. Each business is the mover to lift the valuation of the firm. Employees must constantly improve their talents, knowledge and experience to fulfil this idea. Only such a person may represent a flexible human force, as different techniques and technological developments continue to improve the requirements for each work. Talent management is one of the important tools for nurturing human capital in majority of the industries. This study reveals that talent management practices has done in many sectors specially in banking sectors. It also found that innovative practices of talent management has practiced in service sectors like education sectors, hospitality sectors, IT service, hotel industries etc. Service sector gives more emphasis on talent management compared to manufacturing industry. Within a particular industry, talent management practices greatly vary. Most of the research has done in international perceptive so more research should be done in an Indian context.

\section{REFERENCES}

[1] Alsakarneh, A., A., \& Hong, S., C. (2015). Talent management in twenty - first century: theory and practically: International Journal of Applied Research .1(11),pp. 1036-1043.

[2] B`rezinová, Monika, and Jaroslav Vrchota. (2016). Selected Processes in SMEs, Targeting to South Bohemia Region and Trade Sector. Acta Universitatis Agriculturae et Silviculturae Mendelianae Brunensis. 64(4),pp. 589-94.

[3] Chabault, D., Hulin, A., \& Soparnot, R. (2012). Talent Management in Clusters. Organisational Dynamics, 41(4), pp. $327-$ 335.

[4] Chen, S.-Y. (2012). A study of strategic talent managementworkforce differentiation perspectives (Doctoral thesis). Retrieved fromfile://C:/Users/IANM1564/Downloads/etd002112170312.pdf.(Assesed on 25 Dec 2018).

[5] Collings, David G., Kamel Mellahi, andWayne F. Cascio. (2019). Global talent management and performance in multinational enterprises: A multilevel perspective. Journal of Management. 45(3), pp. 540-66.

[6] Festing, Marion, Lynn Schäfer, and Hugh Scullion. (2013). Talent management in medium-sized German companies: An explorative study and agenda for future research. The International Journal of Human Resource Management. 24(3), pp 1872-93.

[7] Hung, A. (2013). Understanding talent attraction: Perceived attractiveness of financial reward elements. Retrieved from https://open.uct.ac.za/bitstream/item/8711/thesis_com_2014_com_ hung_a.pdf

[8] Hunt, Steven T. (2014). Common Sense Talent Management: Using Strategic Human Resources to Improve Company Performance. Hoboken: JohnWiley \& Sons.

[9] 9.Järvi, Kati, and Violetta Khoreva. (2020). The role of talent management in strategic renewal. Employee Relations: The International Journal. 23(4), pp.231-245.

[10] Jayaraman, S., ParvaizTalib, P., \& Ahmad, F. (2018),. Integrated Talent Management Scale Construction and Initial Validation. Sage Open. 8(3), pp. 1-12.

[11] Kerlinger, F. N. (1973). Review of research in education. F. E. Peacock.

[12] Krishnan, T. N., and Hugh Scullion. 2017. Talent management and dynamic view of talent in small and medium enterprises. Human Resource Management Review. 27(3), pp. 431-41.

[13] Latukha, Marina O. (2018). Talent development and a firm's performance: Evidence from Russian companies. Journal of General Management. 43(2) pp. 51-62.

[14] Latukha, Marina, and Anna Veselova. 2019. Talent management, absorptive capacity, and firm performance: Does it work in China and Russia? Human Resource Management 58(2), pp. 503-519.

[15] Lawler, E. E., III. (2008). Talent: Making people your competitive advantage. San Francisco, CA US: Jossey- Bass. 
[16] Michaels, E., Handfield-Jones, H., \& Axelrod, B. (2001). War for Talent (Hardcover). Boston: Harvard Business School Press Books.

[17] Morley, Michael J., Hugh Scullion, David G. Collings, and Randall S. Schuler. 2015. Talent management: A capital question. European Journal of International Management. 9(2), pp. 1-8.

[18] Nategh M. (2005). Need to Create Bounderiless Organizations, Sanat Khodro journal. 7(1). pp. 155-168.

[19] Paul, N., (2013). Talent management: presentation retrieved at http://www.slideshare.net/NITCALICUT SOMS/talentmanagement-slides

[20] Rana G.(2010). Knowledge Management and E-Learning Activities in the 21st Century to attain Competitive Advantage. Advances In Management, 3(5), pp.54- 56.

[21] Rana G., Sharma R., Singh, S. and Jain, V. (2019). Impact of Employer Branding on Job Engagement and Organizational Commitment in Indian IT Sector. International Journal of Risk and Contingency Management, 8(3), pp.1-17.

[22] Rana, G. and Sharma, R. (2019), "Emerging human resource management practices in Industry 4.0", Strategic HR Review, Vol. 18 No. 4, pp. 176-181.

[23] Rana, G., \& Rastogi, R. (2015). Organizational justice enhancing managerial effectiveness in terms of activity of his position, achieving results and developing further potential. Research on Humanities and Social Sciences, 5 (1), pp.24-31.

[24] Rana, G., Goel,A., Garg, P.( 2010). "Upcoming Trends in Talent Management in Indian Organizations: Empirical Study", HR Journal of Management, 3(1), pp. 16-24.

[25] Rana, G., R Rastogi, Garg, P.(2016).Work Values and Its Impact On Managerial Effectiveness A Relationship In Indian Context. Vision (Sage Publication), 22(3), pp. $300-311$.

[26] Rana,G., \& Goel, AK (2017). Knowledge management process at BHEL: a case study International Journal of Knowledge Management Studies 8 (1-2), pp.115-130.

[27] Rana,G., \& Sharma, R. (2019). Assessing Impact of Employer Branding on Job Engagement: A Study of Banking Sector. Emerging Economy Studies 5 (1), pp7-21.
[28] Sahai, S., \& Srivastava, A.K. (2012). Goal/ target setting and performance assessment as tool for talent management, Procedia Social and Behavioural Sciences, 37, 241-246.

[29] Sparrow, Paul R., and Heba Makram. 2015. What is the value of talent management? Building value-driven processes within a talent management architecture. Human Resource Management Review. 25(3), pp 249-63.

[30] Stahl, Günter, Ingmar Björkman, Elaine Farndale, Shad S. Morris, Jaap Paauwe, Philip Stiles Jonathan Trevor, and Patrick Wright. 2012. Six principles of e ective global talent management. Sloan Management Review. 53(4), pp. 25-42.

[31] Sharma R., Singh S.P., Rana G. (2019) Employer Branding Analytics and Retention Strategies for Sustainable Growth of Organizations. In: Chahal H., Jyoti J., Wirtz J. (eds) Understanding the Role of Business Analytics. Springer, Singapore. https://doi.org/10.1007/978-981-13-1334-9_10.

[32] Sharma.R, Jain.V and Singh.SP(2018),'The Impact of Employer Branding on Organizationalcommitment inIndian IT Sector',IOSR Journal of Business and Management, Vol. 20, No. 1, pp. 49-54. https://doi.org/10.9790/487X-2001054954.

[33] Thunnissen, M., \& Buttiens, D. (2017). Talent Management in Public Sector Organizations: A Study on the Impact of Contextual Factors on the TM Approach in Flemish and Dutch Public Sector Organizations. Public Personnel Management, 46(4), pp. 391-418.

[34] Tymon, W.G., Strumpf, S.A. \& Doh, J.P. (2010). Exploring talent management in India: The neglected role of intrinsic rewards. Journal of World Business, 45(2), pp. 234-246.

[35] Vaiman, V., Scullion H., \& Collings, D. (2012). Talent management decision making. Management Decisions 50 (5): 925 941.

[36] Wellins, R. S., Smith, A. B. \& Erker, S. (2010). Nine Best Practices For effective talent management, White Paper: Pittsburgh, PA: Development Dimensions International (DDI).

[37] Wellins, R. S., Smith, A. B. \& Erker, S. (2010). Nine Best Practices For effective talent management, White Paper: Pittsburgh, PA: Development Dimensions International (DDI).

[38] Yu, D. S. F., Lee, D. T. F., \& Woo, J. (2004). Issues and challenges of instrument translation Western Journal of Nursing Research, 26(13), pp. 301-320. 